\title{
Structuring effective copreneurial teams
}

\author{
S.M. Farrington*, E. Venter and C. Eybers \\ Department of Business Management, Nelson Mandela Metropolitan University, \\ PO Box 77000, Port Elizabeth 6031, Republic of South Africa \\ Shelley.Farrington@nmmu.ac.za \\ C. Boshoff \\ Department of Business Management, University of Stellenbosch, \\ Private Bag X1, Stellenbosch 7600, Republic of South Africa \\ cboshoff@sun.ac.za \\ Received May 2011
}

\begin{abstract}
Despite growing numbers and increased research attention, few empirical studies have focused on copreneurial family businesses, and hardly any guidelines exist on how these couples should manage their marriage and business relationships. Against this background the primary objective of this study was to empirically assess the influence of selected structural-based factors on the effectiveness of South African copreneurships. The teamwork literature proposes that the success of a team depends on how the team is structured or set up, but the empirical findings of this study demonstrate that elements of structure are related to certain measures of success but not to others. More specifically, the results suggest that the success of a marriage between copreneurs is not influenced by the success of the business, but that the more structural elements such as Leadership, Needs alignment and Role clarity are in place, the more satisfied the spouses are likely to be with both their business and their marital relationship.
\end{abstract}

*To whom all correspondence should be addressed.

\section{Introduction}

Family-owned businesses are the most common type of business worldwide (Ibrahim, McGuire \& Soufani, 2009). Their social and economic impact is increasingly being recognised, and the number of family businesses is expected to continue rising in the future (Daryani, Samizadeh \& Tajeddin, 2010; Nieman, 2006; Venter, 2003; IFERA, 2003). Copreneurships are a particular subset of family business where married couples or couples in a marriagelike relationship share in the ownership, management and responsibility of a single business (Wu, Chang \& Zhuang, 2010; Rutherford, Muse \& Oswald, 2006; Barnett \& Barnett, 1988). It is estimated that approximately one third of family businesses are copreneurships (Bjornberg, 2010; Fitzgerald \& Muske, 2002). These husband-and-wife partnerships are receiving increased research attention and reference in the family business literature (Eybers, 2010; Blenkinsopp \& Owens, 2010; Wu et al., 2010; Venter, Farrington \& Boshoff, 2009; Cole \& Johnson, 2007). This increased attention is not surprising, given that much of the growth in entrepreneurship is attributed to an increasing number of husbands and wives going into business together (Fitzgerald \& Muske, 2002). According to Blenkinsopp and Owens (2010), copreneurships are an important phenomenon that justifies future research not only for the purpose of understanding the dynamics between these couples, but also to serve as a foundation for examining the dynamics of other dyadic family relationships found at the centre of the family business.
Despite increased recognition, little research has been undertaken on copreneurships, and few guidelines exist on how these couples should manage their marriage and business relationships (Muske \& Fitzgerald, 2006; Marshack, 1994). Articles in the popular press addressing copreneurial issues are plentiful, but rigorous research based on large empirical samples is scarce (Muske \& Fitzgerald, 2006; Marshack, 1993). In addition, there is a paucity of research that examines whether or not copreneurial couples remain in business together for any length of time (Muske, Fitzgerald, Haynes, Black, Chin, MacClure \& Mashburn, 2009), and the literature is fairly silent on the boundary between work and love between these couples (Bjornberg, 2010). Furthermore, the concept of "copreneurship" is not well recognised and is typically associated with women working in small family businesses (O'Connor, Hamouda, McKeon, Henry \& Johnston, 2006).

Despite their importance to national economies, the survival rate of family businesses, including copreneurships, is extremely low (Nicholson, 2008) and this state of affairs is attributed to the unique problems they face (Nicholson, 2008; Venter, 2003). Several authors (Royer, Simons, Boyd \& Rafferty, 2008; Ward, 2004) suggest that the greatest threats to the growth, success and survival of a family business are primarily issues related to family relationships. The relationship between the spouses in a copreneurship is a particular case in point. Copreneurs face the unique challenge of having to balance their romantic personal relationship and their professional business one (Cole \& 
Johnson, 2007). These relationships often place incongruent demands on the couple, resulting in tension and conflict that have the potential to destroy both their marriage and their business (Danes \& Olson, 2003; Tompson \& Tompson, 2000).

To overcome these potential problems, the structuring of a proper working arrangement among the people involved is particularly important. Uhlaner (2006) suggests that the vast body of research on the effective functioning of teams could make a useful contribution in the structuring of copreneurial partnerships, and that it should be integrated with research in the field of family business. Against this background the primary objective of the present study was to empirically assess the influence of selected structural-based factors identified in the teamwork literature on the effectiveness of South African copreneurships.

This study adds to what is currently known about working arrangements between husbands and wives in joint family businesses, by investigating selected structural-based factors that impact on the partners' levels of satisfaction and business success. It is hoped that by identifying these factors, existing and prospective copreneurs can restructure their working arrangements so as to improve the chances of success in both their business and marriage relationship.

For the purpose of this study a "family business" is a business where a single family owns at least $51 \%$ of the equity of the business; where a single family is able to exercise considerable influence in the business; and where at least two family members are concerned with the senior management of the business. In addition, a "copreneurship" refers to a husband-and-wife team (or life-partners) who share the ownership and/or management of a business, which includes sharing the responsibility for all the activities within that business. The husband and wife (or life-partners) must both be actively involved in the management and/or decision-making of the business, and both must have considerable influence over decision-making in the business. In terms of this definition, the spouses need not share ownership of the business in order to qualify as copreneurs. The concepts "copreneurs", "copreneurial businesses" and "husband-and-wife teams" are used interchangeably and synonymously in this study.

\section{Structuring effective copreneurships}

"The structure of a team" refers to how that team has been configured or put together. A vast amount of information exists on how to configure or build effective teams, and on identifying factors that influence their success (Kozlowski \& Ilgen, 2006; Robbins, 2003). Several seminal models (Cohen \& Bailey, 1997; Campion, Medsker \& Higgs, 1993; Hackman, 1987; Gladstein, 1984) have been proposed on how to build an effective working arrangement between people. Although these models differ in many respects, they address similar issues that are of importance to any group of people who work together, including copreneurs in family businesses.

A common framework underlying these models is that of the input-process-output (I-P-O) framework, which proposes that inputs lead to processes which in turn lead to outputs (Barrick, Stewart, Neubert \& Mount, 1998; Campion et al., 1993; Gladstein, 1984). The I-P-O framework suggests that changes must be made to the design or structural elements of a team if effectiveness is to be improved. According to Guzzo and Dickson (1996), the opportunity to improve team effectiveness lies in how the team has been set up and the context in which it operates. Yancey (1998) contends that input variables such as job design, composition and context can be manipulated and are more directly controllable than, for example, the process variables (Campion et al., 1993). Barrick et al. (1998), as well as Kozlowski and Ilgen (2006) refer to inputs as "the composition of a team and the resources to which they have access". Cohen and Bailey (1997) appropriately name the various input factors as "design factors", which refer to features of the task, group and organisation that can be directly manipulated to create the conditions for effective performance. Against this background, one can conclude that the structural-based elements of a copreneurial team can be managed to increase the chances of their business being successful.

\section{Hypothesised relationships}

For the purpose of this study, the elements identified as relating to structuring or setting up a successful copreneurship are Leadership, Governance, Physical resources, Needs alignment and Role clarity. Effectiveness (success) is measured using three variables, namely Financial performance, Growth performance and Perceived success. Financial performance and Growth performance serve as the intervening variables (although it was not assessed as such using a co-variance modelling analysis to assess direct and indirect effects) whereas Perceived success serves as the dependent variable. The hypothesised relationships between the independent, intervening and dependent variables are depicted in Figure 1. Support for these hypothesised relationships has been found in both the organisational behaviour and the family business literature, and is elaborated on in the paragraphs that follow.

\section{Dependent and intervening variables}

From its beginnings, the field of family business research has revolved around understanding how family businesses become successful or achieve satisfaction. Despite this focus, the debate on how to define success in family firms is ongoing (Zellweger \& Nason, 2009) and a definition of family business "success" remains elusive (Distelberg \& Sorenson, 2009). Astrachan (2006) asserts that no single measure of performance adequately expresses family and business success, and no measure is likely to capture its complexities in the family business environment.

As a result of the absence of a commonly agreed-upon measure of success researchers in the field of family business have focused on performance measures such as levels of employment, profits, sales revenue, and return on assets as indicators of success (Zellweger \& Nason, 2009). These business performance measures have been used by several authors as a means of describing successful family businesses (Casillas, Moreno \& Barbero, 2010; Distelberg \& Sorenson, 2009; Sharma, 2004; Ward, 2004). 


$$
H^{\delta a-} H^{\delta c}
$$

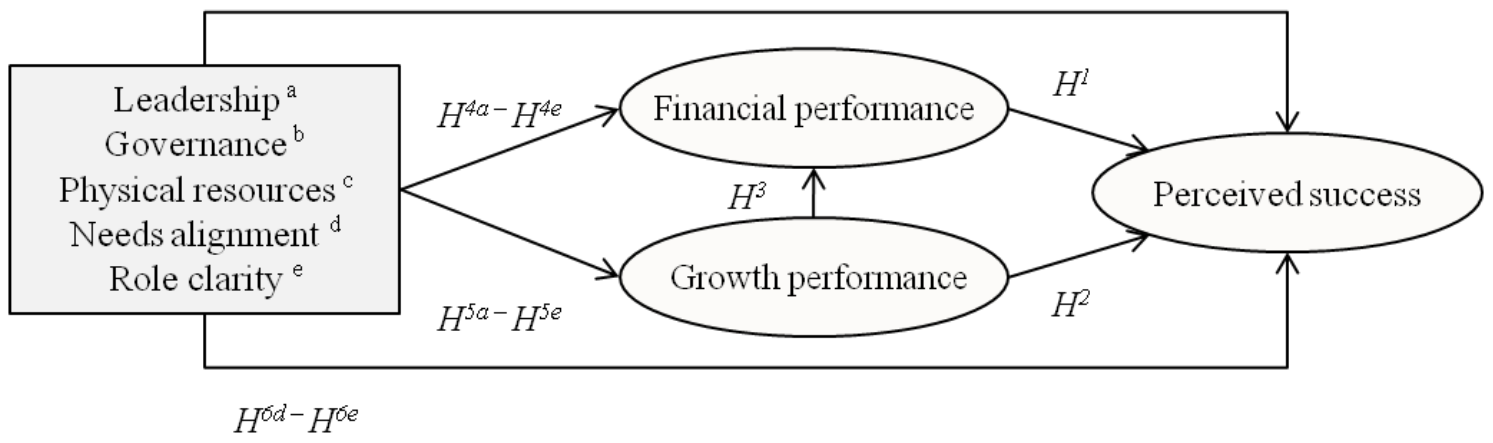

Figure 1: Hypothesised model of structural elements influencing successful copreneurship

"Organisational effectiveness" has been referred to as the ability of an organisation to satisfy the expectations of its strategic constituents. Given this description, it is clear that satisfying one's stakeholders plays a vital role in business success (Zellweger \& Nason, 2009. The satisfaction of family members involved in a family business is commonly associated in family business research with success (Distelberg \& Sorenson, 2009; Zellweger \& Nason, 2009; Ivancevich, Konopaske \& Matteson, 2005; Sharma, 2004; Venter, 2003; Handler, 1991). Against this background the dependent variable of this study is Perceived success, which refers to the copreneurs finding their involvement in the copreneurship to be satisfying and beneficial to their marriage relationship.

Zellweger and Nason (2009) assert that growth in sales and in employee numbers, as well as profitability, are examples of performance outcomes that satisfy the demands of stakeholders. Several empirical studies have revealed a positive relationship between the profitability of the business and the ability to satisfy stakeholders' interests (Adendorff, 2004), as well as between the financial security of the owner-manager and the business, and satisfaction with the succession process (Venter, 2003). Similarly, Farrington (2009) reported a positive relationship between both the growth performance and the financial performance of the business and the extent to which the family members participating in her study were satisfied with their work and family relationships. For the purpose of this study, the Financial performance of the copreneurship refers to the business being financially profitable and secure, whereas the Growth performance of the copreneurship refers to the business showing growth in employee numbers, profits and turnover.

The Perceived success of the copreneurship serves as the dependent variable in this study, whereas the Financial performance and the Growth performance of the copreneurship serve as the intervening variables. The following relationships are hypothesised:

$H^{l}$ : There is a positive relationship between the Financial performance of the copreneurship and the Perceived success of the copreneurship
$H^{2}$ : There is a positive relationship between the Growth performance of the copreneurship and the Perceived success of the copreneurship

Several authors (Brigham \& Daves, 2007; Ittner \& Larcker, 1998) have found support for a positive relationship between the growth performance of a business and its financial performance. In their study analysing 88 different studies, Capon, Farley and Hoenig (1990) reported that growth is consistently related to higher levels of financial performance. The following relationship is therefore hypothesised.

$H^{3}$ : There is a positive relationship between the Growth performance of the copreneurship and the Financial performance of the copreneurship.

\section{Independent variables}

\section{Leadership}

Both anecdotal (Hitt, Miller \& Colella, 2006; Ivancevich et al., 2005) and empirical evidence (Cowie, 2007; Kozlowski \& Ilgen, 2006; Guzzo \& Dickson, 1996; Gladstein, 1984) have found support for a positive relationship between effective leadership and a successful working arrangement. For example, Cowie (2007) reports a significant positive relationship between leadership and the ability of the team to operate efficiently, whereas emerging meta-analytic findings and other empirical evidence support a positive relationship between leadership and team effectiveness (Kozlowski \& Ilgen, 2006). Although Farrington (2009) found no support for a hypothesised positive relationship between leadership and financial performance or between leadership and growth performance in her study, as did other researchers (Sorenson, 2000; Gladstein, 1984), she did find support for a positive relationship between leadership and satisfaction.

Today's rapidly changing business environment has led to new theories of leadership which propose that leaders described as charismatic, transformational or visionary have positive effects on their organisations (Vallejo, 2009). Similarly, Sorenson (2000) concluded that referent, and in particular participative leaders, enable family businesses to obtain desired outcomes for both the business and the family. 
In the present study, the factor Leadership refers to a specific leadership style and may be evident in both spouses, or in either the husband or the wife at a specific time. Leadership refers to the spouse(s) being inspirational, considerate and participatory in their leadership style. For a successful copreneurship to exist, the prevailing leadership style should be flexible and the couple must openly and honestly decide on an appropriate leadership style for their business (Marshack, 2002). Against this background the following relationships are subjected to empirical testing:

$H^{4 a}$ : There is a positive relationship between the existence of Leadership and the Financial performance of the copreneurship

$H^{5 a}$ : There is a positive relationship between the existence of Leadership and the Growth performance of the copreneurship

$H^{6 a}$ : There is a positive relationship between the existence of Leadership and the Perceived success of the copreneurship

\section{Governance}

According to Keen (2003) and Northouse (2004), the existence of norms or codes of conduct that govern their behaviour are important for an effective working relationship between people. A vast amount of anecdotal evidence suggests that the implementation of governance structures, policies and procedures promotes family business success (Gage, Gromala \& Kopf, 2004; Ward, 2004; Lansberg, 1999). In addition, previous empirical research (Adendorff, 2004; Hyatt \& Ruddy, 1997) has found positive relationships between governance practices and financial performance. Venter (2003) and Adendorff (2004) reported positive relationships between governance processes and the profitability of the family business, whereas Hauser (2004) contends that well-governed families lead to well-governed businesses, which in turn earn consistently high profits.

However, both Farrington (2009) and Cowie (2007) reported no relationship between the existence of governance structures and the financial or growth performance of the business. Furthermore, Farrington (2009) found no evidence of a relationship between governance and satisfaction with work and family relationships, whereas Cowie (2007) reported no relationship between the existence of codes of conduct for team members and their willingness to cooperate with and support each other.

Despite governance structures in copreneurial businesses usually being informal (Governance for the family business, 2008), for the purpose of this study Governance refers to the existence of governance structures as well as undertaking strategic planning in the copreneurship. Given the contradictory evidence above, the following relationships are subjected to empirical assessment:

$H^{4 b}$ : There is a positive relationship between the existence of Governance and the Financial performance of the copreneurship.
$H^{5 b}$ : There is a positive relationship between the existence of Governance and the Growth performance of the copreneurship

$H^{6 b}$ : There is a positive relationship between the existence of Governance and the Perceived success of the copreneurship

\section{Physical resources}

For people to work together successfully, the required support and infrastructure to effectively complete the task they are undertaking, must be available (Hitt et al., 2006; Robbins, 2003). Several studies have reported positive relationships between having access to resources and information, and measures of team effectiveness (Doolen, Hacker \& Van Aken, 2006; Hyatt \& Ruddy, 1997; Campion et al., 1993). Furthermore, both Hackman and Walton (1986), and Campion et al. (1993) refer to an organisational environment with the necessary resources (supportive organisational context) as a pre-condition for team effectiveness.

In her study on Sibling Partnerships in family businesses, Farrington (2009) reported significant positive relationships between having access to adequate and suitable resources and both the financial and the growth performance of the business. She concluded that having access to the required resources influenced both the financial and the growth performance of the business more than any of the other factors investigated in her study. Cowie (2007), on the other hand, found no relationship between having access to physical resources and financial performance. In addition, both Farrington (2009) and Cowie (2007) did not find a relationship between the business having access to adequate and suitable resources and measures of satisfaction.

For the purpose of this study Physical resources refer to the copreneurial business having access to the resources and information necessary for the effective functioning of the business. Despite contradictory evidence reported in the literature, the following relationships are hypothesised:

$H^{4 c}$ : There is a positive relationship between the availability of Physical resources and the Financial performance of the copreneurship

$H^{5 c}$ : There is a positive relationship between the availability of Physical resources and the Growth performance of the copreneurship

$H^{6 c}$ : There is a positive relationship between the availability of Physical resources and the Perceived success of the copreneurship

\section{Needs alignment}

According to Iqbal (2010), when the psychological needs of an individual are met in an organisation, the level of commitment by those individuals to that organisation is enhanced. Similarly, Cohen (1992) asserts that when a business serves as a vehicle for individuals to display their abilities and satisfy their needs, such individuals reciprocate 
with commitment to the organisation. Venter (2003) contends that personal needs alignment exists when the needs of family members and the opportunities offered in the business are properly aligned. An individual realises personal needs fulfilment to the extent that his/her career needs, needs for personal identity, and life-stage needs are satisfied in the context of the family business (Venter, 2003; Barach \& Gantisky, 1995). For the purpose of this study, Needs alignment refers to the spouses being able to realise their ambitions and personal goals through their involvement in the business, and this involvement has contributed to their professional growth development. When family members perceive that their career interests and the opportunities available to them in the family business are aligned, they become devoted to that organisation, and make a positive contribution to its success (Sharma \& Irving, 2005).

However, a mismatch between personal and organisational goals decreases an individual's level of job satisfaction and increases his/her intention to leave (Kristof-Brown, Zimmerman \& Johnson, 2005). According to Guzzo and Dickson (1996), when the goals of an organisation and individual goals are in conflict with one another, dysfunctions can result. Several researchers (Venter, 2003; Sharma, 1997) have found that the more a successor can satisfy his/her personal development goals within the business, the more likely it is that he/she will have a positive succession experience. According to Van Auken and Werbel (2006), divergent goals between spouses can result in harmful conflict because a spouse is likely to resist his/her partner's entrepreneurial goals, which in turn will impede the financial performance of the business. Against this background it is hypothesised that:

$H^{4 d}$ : There is a positive relationship between the extent that Needs alignment exists among the spouses and the Financial performance of the copreneurship

$H^{5 d}$ : There is a positive relationship between the extent that Needs alignment exists among the spouses and the Growth performance of the copreneurship

$H^{6 d}$ : There is a positive relationship between the extent that Needs alignment exists among the spouses and the Perceived success of the copreneurship

\section{Role clarity}

For any group of people to work together effectively, it is important that they mutually agree on tasks and responsibilities (Keen, 2003; Robbins, 2003). The job descriptions and responsibilities of each person should be clearly specified (Hitt et al., 2006). Several studies (e.g. Beckman \& Burton, 2005; Ancona \& Caldwell, 1992) have found a relationship between the existence of separate organisational roles and firm performance. For example, Roure and Keeley (1990) report that the degree to which team members hold a variety of positions is related to team success. Furthermore, Beckman and Burton (2005) found strong support for a relationship between functional assignment diversity and the speed at which business outcomes were achieved. In her study Cowie (2007) reported a significant positive relationship between the existence of clear responsibilities and the willingness of her respondents to cooperate with and support each other.

Support for separate positions and areas of responsibility among family members has also been found in the family business literature (Handler, 1991). For example, several authors (Lansberg, 1999; Aronoff, Astrachan, Mendosa \& Ward, 1997; Handler, 1991) contend that siblings working together in family businesses are more effective if they have an explicit agreed-to division of labour, with each sibling enjoying a degree of autonomy in his/her specific area of expertise. Similarly, Stewart-Gross and Gross (2007), and Marshack (1994) contend that the roles of couples who work together should be specific and clearly defined, and the more distinct these roles are, the more advantageous it will be for their business. Clearly defined roles ensure that respect and order are maintained between spouses doing business together (Tompson \& Tompson, 2000) and reduce the likelihood of conflict between them (Husbands, wives and business, 2008; Gale, 2002). In addition, Heffernan (2010) is of the opinion that clearly defined areas of responsibility will ensure that a business has two real employees, as opposed to a "one for the price of two" situation. However, several studies (Eybers, 2010; Farrington, 2009) report no relationships between Role clarity and measures of family business success.

Despite the contradictory evidence, it was decided to empirically test the relationship between Role clarity and the measures of success in this study. Role clarity refers to each spouse being assigned a clearly demarcated area of authority and responsibility in the business, as well as the spouses agreeing on each other's roles and positions in the business. The following relationships are hypothesised:

$H^{4 e}$ : There is a positive relationship between the extent that Role clarity exists among the spouses and the Financial performance of the copreneurship

$H^{5 e}$ : There is a positive relationship between the extent that Role clarity exists among the spouses and the Growth performance of the copreneurship

$H^{6 e}$ : There is a positive relationship between the extent that Role clarity exists among the spouses and the Perceived success of the copreneurship

\section{Methodology}

\section{The measuring instrument}

The variables investigated in this study were measured using reliable and valid items sourced from previous empirical studies, as well as several self-generated items based on secondary sources. Where necessary, the items were rephrased to make them more suitable for the present study. The measuring instrument contained two sections. Section 1 consisted of 39 statements relating to the dependent, intervening and independent variables. Respondents were requested to indicate to what extent they agreed with each statement by means of a 7-point Likert-type scale, interpreted as $1=$ strongly disagree and $7=$ strongly agree . 
Demographic information pertaining to the respondent and the copreneurial business was requested in Section 2.

\section{Sampling and data collection}

Convenience snowball sampling was used to identify potential respondents. The sampling process was initiated by contacting family businesses on two family business databases developed in previous studies (Farrington, 2009; Venter, 2003), as well as those identified via a Google search. Once identified, suitability and willingness to participate in the study were confirmed telephonically. Respondents were requested to identify other copreneurial businesses that could be asked to take part in this study. These potential respondents were then also contacted telephonically and the process was repeated. Several other family business researchers (Farrington, 2009; Van Der Merwe \& Ellis, 2007; Venter, 2003) have adopted this sampling technique and methodology because of the lack of a national database on family firms. In total 1548 potential respondents were identified by means of the sampling technique. In total 380 questionnaires were completed by individual spouses, resulting in a $24.55 \%$ response rate.

\section{Sample description}

Most of the respondents participating in this study were female $(55 \%)$, most were between the ages of 40 and 51 years $(37 \%)$, and most were white $(98 \%)$. Almost half $(49 \%)$ indicated having been in business together with their spouse for 10 years or less. The great majority $(92 \%)$ were actively employed in the business, and most (74\%) reported operating their copreneurship from their family home. Half of the respondents indicated employing 10 or fewer people, and operating their copreneurial businesses in either the retail/services $(30 \%)$ or hospitality $(22 \%)$ industries.

\section{Empirical results}

\section{Discriminant validity and reliability assessment}

An exploratory factor analysis was conducted to assess the discriminant validity of the measuring instrument, and the software programme SPSS 17 for Windows was used for this purpose. Principal axis factoring with an oblique (the factors were expected to correlate) rotation was specified as the extraction and rotation method.

Bartlett's Test of Sphericity $(\mathrm{p}<0.001)$ and Kaiser-MeyerOlkin (KMO) measure of sampling adequacy (0.895) confirmed that the data were factor-analysable. KMO's near 1 support the conclusion that the data are factor-analysable (Rennie, 2002), whereas those below 0.70 are questionable (Kaiser, 1974). The percentage of variance explained and the individual factor loading were considered (see Table 1) when deciding on the number of factors to be extracted. Items that displayed no cross-loadings, that loaded to a significant extent on one factor only, and had factor loadings of $\geq 0.4$, were considered significant (Hair, Black, Babin, Anderson \& Tatham, 2006; Mustakallio, Autio \& Zahra, 2002). Eight factors were extracted explaining a cumulative variance of $70.62 \%$ in the data. Several items (PSUCC4, PSUCC5, ROLE3, ROLE6, PHYS4, PHYS5, PHYS6, LEAD4 and LEAD5) did not load as expected. Only the items that loaded to a satisfactory extent were used in all subsequent analyses including the confirmatory factor analysis and Structural Equation Modelling.

Cronbach-alpha coefficients (CA) were calculated to assess the reliability of the measuring instrument. CA's of greater than 0.70 (Nunnally \& Bernstein, 1994) were returned (see Table 2) for all constructs retained in the final empirical model, suggesting that reliable measuring scales were used to measure the constructs under investigation.

\section{Assessment of hypothesised relationships}

Structural Equation Modelling using the computer programme LISREL 8.80 was the statistical technique used to assess the significance of the relationships hypothesised between the various independent, intervening and dependent variables.

Several fit indices are reported with regard to the structural model. The normed Chi-square $\left(\chi^{2} / \mathrm{df}\right)$ or ratio of $\chi^{2}$ (SatorraBentler Scaled Chi-square 662,534; $p=0,000$ ) to degrees of freedom (349) is 1,898 . Values lower than 2 are indicators of a good fit (Hair, Anderson, Tatham \& Black, 1998). The RMSEA $(0,0487)$ indicates a model with a close fit of the data to the hypothesised model (Hair et al., 1998; Hu \& Bentler 1999). The upper limit of the $90 \%$ confidence interval for RMSEA $(0,0543)$ is less than 0,08 (Roberts, Stephen \& Ilardi, 2003), and the Comparative Fit Index (CFI) is 0,982 . The CFI index should be equal or greater than 0,90 to accept the model and an index close to 1 indicates a very good fit (Garson, 2009). All the fit indices provide evidence of a model with a close fit.

The empirical findings of this study (see Figure 2) reveal no relationship between Financial performance and Perceived success or between Growth performance and Perceived success. Support is thus not found for hypothesis $H^{l}$ or hypothesis $\mathrm{H}^{2}$. However, a positive relationship emerged between the Growth performance and the Financial performance of the copreneurship. Support is thus found for hypothesis $\mathrm{H}^{3}$. 
Table 1: Rotated factor matrix

\begin{tabular}{|c|c|c|c|c|c|c|c|c|}
\hline & 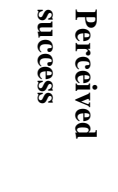 & 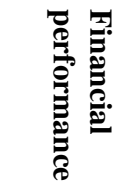 & 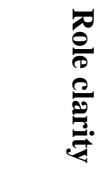 & 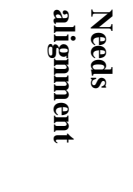 & 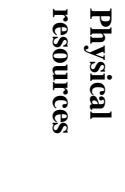 &  & 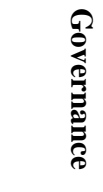 & 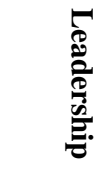 \\
\hline PSUCC2 & ,732 &,- 005 & $\begin{array}{ll}-, 001 \\
\end{array}$ &,- 105 & ,046 & ,022 &,- 078 &, 065 \\
\hline PSUCC6 & ,692 & ,018 & ,142 &,- 057 &,- 049 &,- 003 &,- 033 &, 113 \\
\hline PSUCC7 &, 615 &,- 021 & , 193 &,- 136 & ,026 & ,018 & ,041 &, 083 \\
\hline PSUCC1 & ,507 & , 147 &,- 012 &,- 009 &, 016 &,- 083 &,- 305 & ,167 \\
\hline PSUCC 3 & ,427 &,- 036 & ,081 &,- 374 & ,092 &,- 003 &,- 130 & ,049 \\
\hline FIN1 & ,043 & ,841 & ,022 & ,018 &,- 015 & , 140 & , 045 & ,046 \\
\hline FIN2 & ,003 &, 810 &,- 007 &,- 117 & ,029 & ,092 &,- 044 &,- 034 \\
\hline FIN3 &,- 082 &, 578 &, 103 &,- 031 & ,209 & ,034 &,- 093 &, 077 \\
\hline ROLE5 & $\begin{array}{l}, 014 \\
\end{array}$ &,- 035 & ,722 &, 016 & ,044 & ,003 &,- 018 & ,040 \\
\hline ROLE2 & ,082 &,- 107 & ,697 & 057 & ,009 &, 100 &,- 170 &, 029 \\
\hline ROLE4 & ,023 &, 115 &, 585 &,- 022 & ,006 &,- 030 &, 050 &,- 049 \\
\hline ROLE1 & , 144 &,- 033 & ,433 &, 028 & ,056 & ,013 &,- 146 &, 120 \\
\hline NEED4 & $\begin{array}{l}, 007 \\
\end{array}$ &, 050 &,- 040 &,- 827 & ,080 &,- 047 &,- 083 &,- 018 \\
\hline NEED5 & ,098 & 075 & ,002 &,- 714 &,- 036 & 074 &,- 122 &,- 030 \\
\hline NEED6 & ,243 &,- 022 & ,009 & $\begin{array}{l}-, 461 \\
\end{array}$ & ,142 & ,091 &, 105 &, 153 \\
\hline PHYS3 & ,049 &,- 090 & ,025 &,- 044 & ,783 & ,093 &, 025 & ,091 \\
\hline PHYS1 &,- 074 & , 189 & ,064 &,- 073 & ,734 &,- 075 &, 033 &,- 005 \\
\hline PHYS2 & , 011 & 064 & ,037 &, 015 &, 543 & ,024 &,- 311 &,- 078 \\
\hline GROW1 & , 149 &, 150 &,- 003 & 066 &, 074 & ,779 &, 032 &,- 048 \\
\hline GROW3 & ,067 &, 323 & $\begin{array}{ll}-, 024 \\
\end{array}$ & ,021 &,- 024 & ,739 &,- 053 &,- 009 \\
\hline GROW2 &,- 185 &,- 049 & 056 &,- 123 & ,002 & ,452 &,- 060 &, 084 \\
\hline GOV1 & , 102 &, 024 &,- 046 &, 027 &, 069 &, 118 &,- 703 &,- 008 \\
\hline GOV2 &, 014 &,- 012 & ,050 &,- 168 &,- 032 & ,017 & $\begin{array}{l}-647 \\
\end{array}$ & ,044 \\
\hline GOV3 &,- 096 &, 079 & , 153 &,- 028 &, 038 &,- 089 &,- 556 & ,113 \\
\hline GOV4 & ,056 &,- 055 & ,092 &,- 053 & ,011 & ,051 &,- 518 &, 000 \\
\hline GOV5 & ,028 & , 105 & ,043 &,- 102 & , 101 &,- 047 &,- 450 & , 103 \\
\hline LEAD3 &,- 103 &, 025 & ,154 &,- 099 &,- 101 & 051 & ,011 &, 707 \\
\hline LEAD6 & ,173 & ,099 &,- 067 &,- 016 & ,008 &,- 089 &,- 034 & ,706 \\
\hline LEAD1 & ,075 &,- 027 &,- 035 & ,096 & , 044 &,- 001 &,- 081 &, 667 \\
\hline LEAD2 &, 056 &,- 037 & ,016 &,- 048 & ,239 & , 119 &, 016 &, 538 \\
\hline$\% \mathrm{VE}^{*}$ & 34,00 & 9,98 & 6,15 & 5,15 & 4,37 & 4,23 & 3,74 & 2,99 \\
\hline \% CVE** & 34,00 & 43,98 & 50,13 & 55,28 & 59,65 & 63,88 & 67,62 & 70,6 \\
\hline
\end{tabular}

$* \% \mathrm{VE}=$ Percentage variance explained

$* * \% \mathrm{CVE}=$ Percentage cumulative variance explained

Table 2: Measurement instrument analyses

Operationalisation of factors

Perceived success refers to the copreneurs finding their involvement in the copreneurship as satisfying and beneficial to their marriage relationship.

Financial performance refers to the business being financially profitable and secure.

Growth performance refers to the business showing growth in employee numbers, profits and turnover.

Role clarity refers to each spouse being assigned a clearly demarcated area of authority and responsibility in the business, as well as the spouses agreeing on each other's roles and positions in the business.

Needs alignment refers to the spouses being able to realise their ambitions and personal goals through their involvement in the business, and this involvement having contributed to their professional growth development.

Physical resources refers to the copreneurial business having access to the resources and information necessary for the effective functioning of the business.

Governance refers to the existence of governance structures as well undertaking strategic planning in the copreneurship.

Leadership refers to the spouse(s) being inspirational, considerate and participatory in their leadership style.

\begin{tabular}{|c|c}
\hline Items $^{*}$ & $\begin{array}{c}\text { Cronbach-alpha } \\
\text { values }\end{array}$ \\
\hline 5 & 0,885 \\
\hline 3 & 0,872 \\
\hline 3 & 0,700 \\
\hline 4 & 0,771 \\
\hline 3 & 0,820 \\
\hline 3 & 0,812 \\
\hline 5 & 0,803 \\
\hline 4 & 0,809 \\
\hline
\end{tabular}

*See Appendix A for a detailed description of multiple item scales measuring factors 
$H^{6 a} 0.39 ; p<0.001 \quad H^{6 b-6 c}=N S$

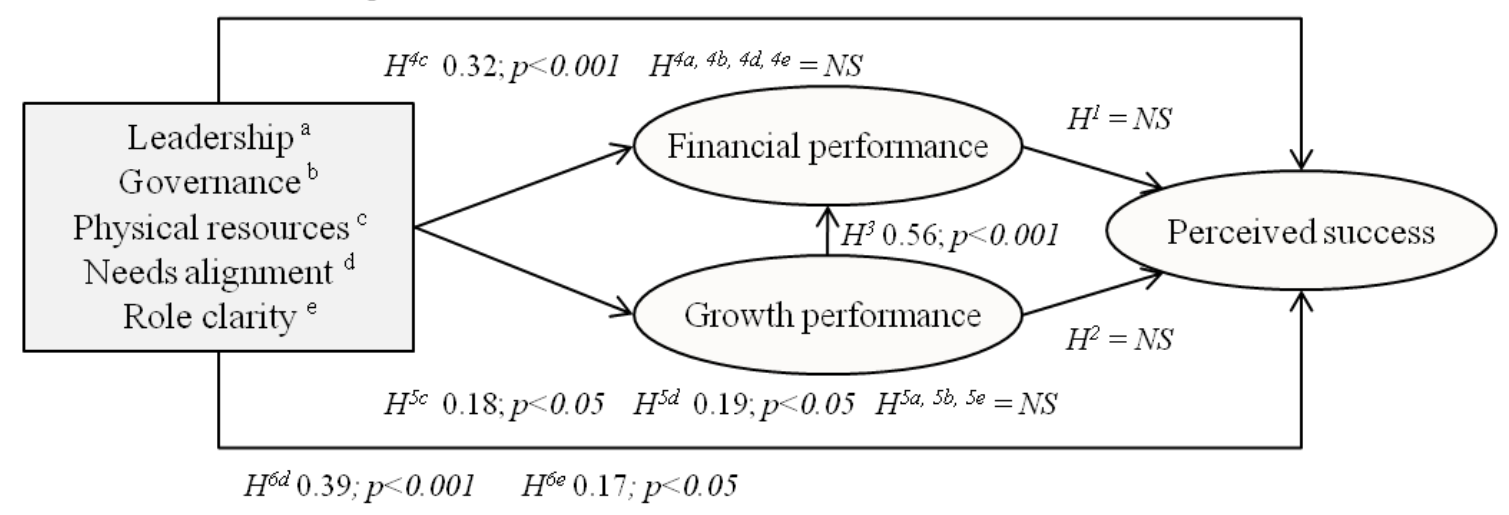

Figure 2: Summary of significant relationships

The independent variables Leadership $\left(H^{6 a}\right.$, path coefficient $=0,39, \mathrm{p}<0,001)$, Needs alignment $\left(H^{6 d}\right.$, path coefficient $=$ $0,39, \mathrm{p}<0,001)$ and Role clarity $\left(H^{6 e}\right.$, path coefficient $=0,17$, $\mathrm{p}<0,05)$ are all positively related to Perceived success, and Needs alignment $\left(H^{5 d}\right.$, path coefficient $\left.=0,19, \mathrm{p}<0,05\right)$ is also positively related to Growth performance. Physical resources is positively related to both Financial performance $\left(H^{4 c}\right.$, path coefficient $\left.=0,32, \mathrm{p}<0,001\right)$ and Growth performance $\left(H^{5 c}\right.$, path coefficient $\left.=0,18, \mathrm{p}<0,05\right)$. Support was thus found for hypotheses $H^{4 c}, H^{5 c}, H^{5 d}, H^{6 a}$, $H^{6 d}$ and $H^{6 e}$ hypotheses.

The results of this study, however, reveal no empirical support for the hypothesised relationships between the independent variables Governance (hypothesis $H^{6 b}$ ) and Physical resources (hypothesis $H^{6 c}$ ) and the dependent variable Perceived success. Similarly, no empirical support was found for the hypothesised relationships between the independent variables Leadership (hypothesis $H^{4 a}$ ), Governance (hypothesis $H^{4 b}$ ), Needs alignment (hypothesis $H^{4 d}$ ) and Role clarity (hypothesis $H^{4 e}$ ) and the intervening variable Financial performance. Furthermore, no support was found for the hypothesised relationship between Leadership (hypothesis $H^{5 a}$ ), Governance (hypothesis $H^{5 b}$ ) and Role clarity (hypothesis $H^{5 e}$ ) and the intervening variable Growth performance. In summary no support was found for hypotheses $H^{4 a}, H^{4 b}, H^{4 d}, H^{4 e}, H^{5 a}, H^{5 b}, H^{5 e}, H^{6 b}$ and $H^{6 c}$.

\section{Discussion}

The primary objective of this study was to empirically assess the influence of selected structural-based factors on the effectiveness of South African copreneurships. The teamwork literature suggests that the success of a team depends on how the team is structured when originally set up. However, the empirical findings of this study show that some of the structural elements are related to certain measures of success but not to others. For example, the results of this study show that the existence of a leadership style that is inspirational, considerate and participatory in a copreneurship has a significant positive influence on the extent to which the spouses experience their involvement in the copreneurship as satisfying and beneficial to their marriage relationship. However, such a leadership style has no influence on the financial or growth performance of the business. That copreneurs would experience their involvement in a coprenership as satisfying under such leadership conditions is not surprising. However, the findings with regard to the relationship between Leadership and the measures of business performance seem to suggest that another leadership style might be more advantageous to the performance of the business. A different leadership style could, however, negatively influence the levels of satisfaction experienced by the spouses. The importance of balancing the needs of both the business and the personal relationship between the spouses is highlighted by this finding.

A significant positive relationship emerged between the independent variable Role clarity and the dependent variable Perceived success. In other words, the more the spouses were assigned clearly demarcated areas of authority and responsibility in the business, and agreed on these responsibilities, the more likely the copreneurs were to experience their involvement in the business together as satisfying and beneficial to their marital relationship. Given that one of the main challenges facing copreneurs is the management of their marital relationship, separate business positions and responsibilities allow each spouse a certain degree of independence and space from the other. Because of their continual interaction at both home and at work, clearly demarcated business responsibilities allow them to get on with their daily activities and make decisions without interference from their spouse. It seems that a certain amount of "alone" time is vital for any relationship. However, no relationship emerged between Role clarity and the intervening variables, Financial performance and Growth performance. This result implies that the existence of clearly assigned responsibilities between the spouses has no influence on the perceived performance of the business.

The independent variable Needs alignment is significantly positively related to Growth performance and Perceived success, but not to Financial performance. This result implies that the more the spouses are able to realise their goals and develop professionally through their involvement in business together, the more likely they are to experience this involvement as satisfying. This finding is not surprising as it is only when individuals are achieving their personal goals that they are satisfied and prepared to invest time and effort to enable a business to grow. The results of this study do, however, imply that that whether Needs alignment exists or not has no influence on the financial profitability and 
security of the business.

The findings of this study show that the factor Physical resources is positively related to both Financial performance and Growth performance but not to Perceived success. Having access to the required resources and information significantly influences the performance of the business, but has no influence on whether the copreneurs find their involvement in the business to be satisfying. Copreneurial businesses need to realise that if their business is to perform satisfactorily, adequate investments must be made to acquire the required resources to undertake operations.

As in the case of several other studies (Farrington, 2009; Cowie, 2007; Venter, 2003), no empirical support was found for the relationships hypothesised between Governance and the different measures of success in this study. This finding implies that whether or not governance structures exist in the copreneurship and whether or not strategic planning is undertaken, has no influence on the satisfaction levels of the spouses or on the performance of their business. An explanation for this finding could be the general absence of governance structures in family businesses (Dunn, 1999; Maas, 1999) and the informal nature of these structures in copreneurial businesses (Governance for the family business, 2008). It is not likely that Governance would influence the success of the copreneurships participating in this study if their structures were non-existent or of an informal nature.

No relationship was found between the intervening variables Financial performance and Growth performance, and the dependent variable Perceived success. In other words, whether the business is performing satisfactorily financially or showing evidence of growth or not has no influence on whether the spouses experience their involvement in the copreneurship as satisfying and beneficial to their marriage relationship. This finding appears to contradict the common adage "when money troubles walk in the front door, love walks out the back door". Furthermore, this finding suggests that the structural-based elements investigated in this study do not influence the satisfaction levels of spouses indirectly through the Financial performance and the Growth performance of the business. As in the case of several other studies (Farrington, Venter \& Boshoff, 2011; Brigham \& Daves, 2007), a significant positive relationship exists between the Growth performance and the Financial performance of the business. The more the business experiences growth, the more likely is the perception among the copreneurs that the business will perform financially.

\section{Implications and contributions}

This study provides insights into the structuring a successful working arrangement between husbands and wives. It is suggested that couples wanting to go into business together should ensure that the structural elements investigated in this study form part of their working arrangement, should they wish a satisfactory outcome.

An interesting finding of this study is that whether the business is financially successful or not has no influence on the spouses experiencing their involvement in business together as satisfying and beneficial to their marriage relationship. In other words, the success of their marriage is not influenced by the success of their business. Couples are encouraged to identify the factors that do influence the success of their marriage, and ensure that they are given the necessary attention. Leadership, Needs alignment and Role clarity are structural elements that could moderate and influence the relationship between the spouses. The more these elements are in place the more satisfied the spouses are likely to be.

Both copreneurial couples and family business practitioners should take note that in order to function effectively and perform well financially, copreneurships need access to adequate physical resources to execute their responsibilities. The appropriate information necessary to make decisions and to complete tasks should be accessible when needed. Although the results of this study show that the performance of the business has no influence on the success of the marriage, a failed business will do little to financially support a happily married couple.

This study adds to the field of family business research by investigating copreneurships in family businesses. The use of Structural Equation Modelling and a relatively large sample enhances the contribution if one considers that most studies on copreneurs have focused on the case study methodology only. Taking the theories related to structuring effective teams into account, this study has tested these theories among husband-and-wife teams in family businesses. By applying teamwork theories to the family business context, the study has also modestly contributed to teamwork literature.

\section{Limitations and future research}

In most studies done on teams, the focus is on assessing the team's perceptions rather than on the perceptions of individuals. Analysis is done at the team level and not at the individual level (Doolen et al., 2006; Wageman, Hackman \& Lehman, 2005). A limitation of this study is that in contrast to most studies done on teams the analysis was done at the individual level and not at the team level. In order to allow for an overall perspective and increased validity, future studies on copreneurs could assess the perceptions of the husband and wife together, by averaging their responses with regard to the factors under investigation.

Snowball convenience sampling does not always create representative samples (Zikmund, 2003) and using this technique is a limitation of this study. In future research, an effort should be made to develop a more comprehensive database from which probability samples can be drawn. This limitation in family business research is, however, likely to be ongoing, given the challenges researchers face in compiling databases on family businesses.

A further limitation of this study is that it focuses on selected structural-based factors only and does not consider the numerous other factors, such as the marriage relationship of the spouses, the communication and fairness between the 
spouses, the existence of children, and operating the business from the family home, which could potentially influence the successful functioning of a copreneurship. Future studies should investigate these factors.

\section{Acknowledgement}

The paper is based on work financially supported by the National Research Foundation of South Africa.

\section{References}

Adendorff, C.M. 2004. 'The development of a cultural family business model of good governance for Greek family businesses in South Africa'. Unpublished doctoral thesis, Rhodes University, Grahamstown.

Ancona, D. \& Caldwell, D.F. 1992. 'Demography and design: Predictors of new product team performance', Organizations Science, 3: 321-341.

Aronoff, C.E., Astrachan, J.H., Mendosa, D.S. \& Ward, J.L. 1997. Making sibling teams work: The next generation. Marietta, GA: Family Enterprise Publishers.

Astrachan, J.H. 2006. 'Editor's notes', Family Business Review, 19(1): v-vi.

Barach, J.A. \& Gantisky, J.B. 1995. 'Successful succession in family business', Family Business Review, 8(2): 131-155.

Barnett, F. \& Barnett, S. 1988. Working together: Entrepreneurial couples. Berkeley, CA: Ten Speed Press.

Barrick, R.B., Stewart, G.L., Neubert, M.J. \& Mount, M.K. 1998. 'Relating member ability and personality to workteam processes and team effectiveness', Journal of Applied Psychology, 83(3): 377-391.

Beckman, C.M. \& Burton, M.D. 2005. 'Founding the future: The evolution of top management teams from founding to IPO'. [online]

URL:http//web.mit.edu/burton/www/FoundingtheFuture.Fin al.April.2005.

Blenkinsopp, J. \& Owens, G. 2010. 'At the heart of things: The role of the "married" couple in entrepreneurship and family business', International Journal of Entrepreneurial Behaviour \& Research, 16(5): 357-369.

Bjornberg, A. 2010. 'Husband and wife teams: Challenges and possibilities of copreneurship'. [online] URL:http//familybusinesswiki.ning.com/profiles/blog/show ?id=258481\%3ABlogPost $\% 3$.

Brigham, E. \& Daves, P. 2007. Intermediate financial management. 9th Edition. Mason, $\mathrm{OH}$ : Thomson Learning.

Campion, M.A., Medsker, G.J. \& Higgs, A.C. 1993. 'Relations between work group characteristics and effectiveness: Implications for designing effective work groups', Personnel Psychology, 46: 823-850.
Capon, N., Farley, J.U. \& Hoenig, S. 1990. 'Determinants of financial performance: A meta-analysis', Management Science, 36(10): 1143-1159.

Casillas, J.C., Moreno, A.M. \& Barbero, J.L. 2010. 'A configurational approach to the relationship between entrepreneurial orientation and growth of family firms', Family Business Review, 23(1): 27-44.

Cohen, A. 1992. 'Antecedents of organisational commitment across occupational groups: A meta-analysis', Journal of Organisational Behaviour, 13(6): 539-558.

Cohen, S.G. \& Bailey, D.E. 1997. 'What makes teams work: Group effectiveness research from the shop-floor to the executive suite', Journal of Management, 23(3): 239-290.

Cole, P.M. \& Johnson, K. 2007. 'An exploration of successful copreneurial relationships postdivorce', Family Business Review, 20(3): 185-198.

Cowie, L. 2007. 'An investigation into the components impacting the effective functioning of management teams in small businesses'. Unpublished honours treatise, Nelson Mandela Metropolitan University, Port Elizabeth.

Danes, S.M. \& Olson, P.D. 2003. 'Women's role involvement in family businesses, business tension, and business success', Family Business Review, 16(1): 53-68.

Daryani, M.A., Samizadeh, M. \& Tajeddin, M. 2010. 'Family factors and the criterion of family businesses in developing countries: A case study of Iran's oil and textile industries', African Journal of Business Management, 4(10): 2140-2149.

Distelberg, B. \& Sorenson, R.L. 2009. 'Updating systems concepts in family businesses: A focus on values, resource flows, and adaptability', Family Business Review, 22(1): 6581.

Doolen, T.L., Hacker, M.E. \& Van Aken, E. 2006. 'Managing organizational context for engineering team effectiveness', Team Performance Management, 12(5/6): 138-154.

Dunn, B. 1999. 'The family factor: The impact of family relationship dynamics on business-owning families during transitions', Family Business Review, 12(1): 41-60.

Eybers, C. 2010. 'Copreneurs in South African small and medium-sized family businesses'. Unpublished masters dissertation, Nelson Mandela Metropolitan University, Port Elizabeth.

Farrington, S.M. 2009. 'Sibling Partnerships in South African small and medium-sized family businesses'. Unpublished doctoral thesis, Nelson Mandela Metropolitan University, Port Elizabeth.

Farrington, S.M., Venter, E. \& Boshoff, C. 2011. 'The impact of intra-group processes on family business success', 
South African Journal of Economic and Management Sciences, 14(1): 8-23.

Fitzgerald, M.A. \& Muske, G. 2002. 'Co-preneurs: An exploration and comparison to other family businesses', Family Business Review, 15(1): 1-16.

Gage, D., Gromala, J. \& Kopf, E. 2004. 'Successor partners: Gifting or transferring a business or real property to the next generation', ACTEC Journal, 30(3): 193-197.

Gale, T. 2002. 'Entrepreneurial couples. Encyclopaedia of small business.' [online] URL:http://www.accessmylibrary. com/coms2/summary_0193-12289_ITM.

Garson, G.D. 2009. 'Structural Equation Modeling'. [online] URL:http://faculty.chass.ncsu.edu/garson/PA765/structur.ht $\mathrm{m}$.

Gladstein, D.L. 1984. 'Groups in context: A model of task group effectiveness', Administrative Science Quarterly, 29: 499-517.

'Governance for the family business'. 2008. KPMG.ca. [online]

URL:http://www kpmg.ca/en/services/enterprise/issuesGro wthGovernance html.

Guzzo, R.A. \& Dickson, M.D. 1996. 'Teams in organizations: Recent research on performance and effectiveness', Аnnu. Rev. Psychol, 47: 307-338.

Hackman, J.R. \& Walton, R.E. 1986. 'Leading groups in organisations'. In Yancey, M. 1998. 'Work teams: Three models of effectiveness'. [online] URL:http://www.workteams.unt.edu/literature/papermyancey html.

Hackman, J.R. 1987. 'The design of work teams'. In Campion, M.A., Medsker, G.J. \& Higgs, A.C. 1993. 'Relations between work group characteristics and effectiveness: Implications for designing effective work groups', Personnel Psychology, 46: 823-850.

Hair, J.F., Anderson, R.E., Tatham, R.L. \& Black, W.C. 1998. Multivariate data analysis. 5th Edition. Englewood Cliffs, NJ: Prentice Hall.

Hair, J.F., Black, W.C., Babin, J.B., Anderson, R.E. \& Tatham, R.L. 2006. Multivariate data analysis. 6th Edition. Upper Saddle River, New Jersey: Pearson/Prentice Hall.

Handler, W.C. 1991. 'Key interpersonal relationships of next-generation family members in family firms', Journal of Small Business Management, 29(3): 21-32.

Hauser, B. 2004. 'Family governance in 2004: Parallels from world politics and corporate boardrooms', The Journal of Wealth Management, Summer. [online] URL:http://www.iijournals.com/JPPM/default.asp?Page=2\& ISS $=10261 \&$ SID $=412355$.
Heffernan, M. 2010. Copreneurs: Do you really want to go into business with your spouse?' [online] URL: http://www.bnet.com/blog/business-strategy/copreneurs-doyou-really-want-to-go-into-business-with-your-spouse/330.

Hitt, M.A., Miller, C.C. \& Colella, A. 2006. Organisational behavior: A systematic approach. United States of America, NY: John Wiley.

Hu, L. \& Bentler, P.M. 1999. 'Cutoff criteria for fit indexes in covariance structure analysis' conventional criteria versus new alternatives'. In Adendorff, C.M. 2004. 'The development of a cultural family business model of good governance for Greek family businesses in South Africa'. Unpublished doctoral thesis, Rhodes University, Grahamstown.

Husbands, wives and business. 2008. Small Business Solutions, New York Life. [online] URL:http://www.newyorklife.com/cda/0,3254,13979,00 ht $\mathrm{ml}$.

Hyatt, D.E. \& Ruddy, T.M. 1997. 'An examination of the relationship between work group characteristics and performance: Once more into the breech', Personnel Psychology, 50: 553-585.

Ibrahim, A.B., McGuire, J. \& Soufani, K. 2009. 'An imperical investigation of factors contributing to longevity of small family firms', Global Economy \& Finance Journal, 2(2): 1-21.

IFERA. 2003. 'Family businesses dominate', Family Business Review, 16(4): 235 - 240.

Ittner, C.D. \& Larcker, D.F. 1998. 'Are nonfinancial measures leading indicators of financial performance? An analysis of customer satisfaction', Journal of Accounting Research, 36: 1-35.

Iqbal, A. 2010. 'An empirical assessment of demographic factors, organisational ranks and organisational commitment', International Journal of Business and Management, 5(3): 16-27.

Ivancevich, J., Konopaske, I. \& Matteson, M. 2005. Organisational behavior and management. $7^{\text {th }}$ Edition. New York, NY: McGraw-Hill.

Kaiser, H.F. 1974. 'An index of factorial simplicity', Psychometrika, 39: 31-36.

Keen, T.R. 2003. Creating effective and successful teams. United States of America, IN: Purdue University Press.

Kozlowski, S.W.J. \& Ilgen, D.R. 2006. 'Enhancing the effectiveness of work groups and teams', Psychological Science in the Public Interest, 7(3): 77-124.

Kristof-Brown, A.L., Zimmerman, R.D. \& Johnson, E.C. 2005. 'Consequences of individuals' fit at work: A metaanalysis of person-job, person-organization, person-group, and person-supervisor fit', Personnel Psychology, 58(2): 
281-342.

Lansberg, I. 1999. Succeeding generations: Realising the dreams of families in business. Boston, MA: Harvard Business School Press.

Maas, G. 1999. 'Family businesses in South Africa: A development model'. Paper presented at the SAESBA Conference, 30 July - 1 August, pp. 1-15.

Marshack, K.J. 1993. 'Coentrepreneurial couples: A literature review on boundaries and transitions among copreneurs', Family Business Review, 6(4): 355-369.

Marshack, K.J. 1994. 'Copreneurs and dual-career couples: Are they different?', Entrepreneurship: Theory \& Practice, 19(1): 49-69.

Marshack, K.J. 2002. 'Cultivating resilient leadership can help a family business to succeed', Vancouver Business Journal Weekly, 23 August.

Muske, G. \& Fitzgerald, M.A. 2006. 'A panel study of copreneurs in business: Who enters, continues, and exits?', Family Business Review, 19(3): 193-205.

Muske, G., Fitzgerald, M.A., Haynes, G., Black, M., Chin, L., MacClure, R. \& Mashburn, A. 2009. 'The intermingling of family and business financial resources: Understanding the Copreneurial couple', Journal of Financial Counselling and Planning, 20(2): 27-47.

Mustakallio, M., Autio, E. \& Zahra, A. 2002. 'Relational and contractual governance in family firms: Effects on strategic decision making', Family Business Review, XV(3): 205-222.

Nicholson, N. 2008. 'Evolutionary Psychology and family business: A new synthesis for theory, research and practice', Family Business Review, 21(1): 103-118.

Nieman, G. (Ed.). 2006. Small business management: A South African approach. Pretoria, GA: Van Schaik.

Northouse, P.G. 2004. Leadership: Theory and practice. 3rd Edition. United States of America, CA: Sage.

Nunnally, J.C. \& Bernstein, I.H. 1994. Psychometric theory. $3^{\text {rd }}$ Edition. New York, NY: McGraw-Hill.

O'Connor, V., Hamouda, A., McKeon, H., Henry, C. \& Johnston, K. 2006. 'Co-entrepreneurial ventures: A study of mixed gender founders of ICT companies in Ireland', Journal of Small Business and Enterprise Development, 13(4): 600-619.

Rennie, H.G. 2002. 'A geography of marine farming rights in New Zealand: Some rubbings of patterns on the face of the sea.' Unpublished doctoral thesis, University of Waikato, New Zealand.

Robbins, S.P. 2003. Organisational behavior. $10^{\text {th }}$ Edition. United States of America: Prentice-Hall.
Roberts, M.C., Stephen, S. \& Ilardi, S.S. 2003. Handbook of research methods in clinical psychology. Oxford: Blackwell Publishing.

Roure, J. \& Keely, R. 1990. 'Predictors of success in new technology based ventures'. In Farrington, S.M. 2009. 'Sibling Partnerships in South African small and mediumsized family businesses'. Unpublished doctoral thesis, Nelson Mandela Metropolitan University, Port Elizabeth.

Royer, S., Simons, R., Boyd, B. \& Rafferty, A. 2008. 'Promoting family: A contingency model of family business succession', Family Business Review, 21(1): 15-30.

Rutherford, M.W., Muse, L.A. \& Oswald, S.L. 2006. 'A new perspective on the developmental model for family business', Family Business Review, 19(4): 317-333.

Sharma, P. 1997. 'Determinants of the satisfaction of the primary stakeholders with the succession process in family firms'. Unpublished doctoral thesis, University of Calgary, Canada.

Sharma, P. 2004. 'An overview of the field of family business studies: Current status and directions for the future', Family Business Review, 17(1): 1-36.

Sharma, P. \& Irving, G. 2005. 'Four bases of family business successor commitment: Antecedents and consequences', Entrepreneurship Theory and Practice, 29(1): 13-33.

Sorenson, R.L. 2000. 'The contribution of leadership style and practices to family and business success', Family Business Review, 13(3): 183-199.

Stewart-Gross, B.L. \& Gross, M.J. 2007. Sleeping with your business partner. Sterling, VA: Capital Books, Inc.

Tompson, G.H. \& Tompson, H.B. 2000. 'Determinants of successful co-preneurship'. Conference paper presented at the ICSB World Conference, 2-4 June, Brisbane, Australia.

Uhlaner, L.M. 2006. 'Business family as a team: underlying force for sustained competitive advantage'. In Poutziouris, P., Smyrnios, K. \& Klein, S. (Eds.). 2006. Handbook of research on family business. Bodmin, Cornwall: Edward Elgar Publishing.

Vallejo, M.C. 2009. 'Analytical models of leadership in family firms under transformational theoretical approach', Family Business Review, 22(2): 136-150.

Van Auken, H. \& Werbel, J. 2006. 'Family dynamic and family business financial performance: Spousal commitment', Family Business Review, 19(1): 49-63.

Van der Merwe, S.P. \& Ellis, S. 2007. 'An exploratory study of some of the determinants of harmonious family relationships in small and medium-sized family businesses', Management Dynamics, 16(4): 24-35. 
Venter, E. 2003. 'The succession process in small and medium-sized family businesses in South Africa'. Unpublished doctoral thesis, University of Port Elizabeth, Port Elizabeth.

Venter, E., Farrington, S.M. \& Boshoff, H.C. 2009. 'Selected relational-based factors that impact on the successful functioning of copreneurial businesses: A proposed conceptual model', Management Dynamics, 18(22): 2-20.

Wageman, R., Hackman, J.R. \& Lehman, E.V. 2005. 'Team diagnostic survey: Development of an instrument', The Journal of Applied Behavioural Science, 41(4): 373-398.

Ward, J.L. 2004. Perpetuating the family business. 50 lessons learned from long-lasting successful families in business. New York, NY: Palgrave Macmillan.
Wu, M., Chang, C-C. \& Zhuang, W-L. 2010. 'Relationships of work-family conflict with business and marriage outcomes in Taiwanese copreneurial women', The International Journal of Human Resource Management, 21(5): 742-753.

Yancey, M. 1998. 'Work teams: Three models of effectiveness'. [online] URL:http://www.workteams.unt.edu/literature/papermyancey.html.

Zikmund, W.G. 2003. Business research methods. $7^{\text {th }}$ Edition. Mason, IO: South Western Thomson.

Zellweger, T.M. \& Nason, R.S. 2009. 'A stake stakeholder perspective on family firm performance', Family Business Review, 21(3): 203-216. 
Appendix 1: Items measuring constructs

\begin{tabular}{|c|c|}
\hline \multicolumn{2}{|c|}{ PERCEIVED SUCCESS } \\
\hline PSUCSS1 & I am satisfied with the way that my spouse and I work together. \\
\hline PSUCSS2 & I enjoy working with my spouse in our family business. \\
\hline PSUCSS3 & I experience my involvement in this business together with my spouse as rewarding. \\
\hline PSUCSS6 & My involvement in this business together with my spouse has been beneficial to our marriage relationship. \\
\hline PSUCSS7 & $\begin{array}{l}\text { My involvement in this business together with my spouse has improved the health of our marriage } \\
\text { relationship. }\end{array}$ \\
\hline \multicolumn{2}{|c|}{ FINANCIAL PERFORMANCE } \\
\hline FIN1 & Our family business is profitable. \\
\hline FIN2 & I regard our family business as being financially successful. \\
\hline FIN3 & The financial well-being of our family business is secure. \\
\hline \multicolumn{2}{|c|}{ GROWTH PERFORMANCE } \\
\hline GROW1 & Our family business has experienced growth in turnover over the past two years. \\
\hline GROW2 & Our family business has experience growth in employee numbers over the past two years. \\
\hline GROW3 & Our family business has experienced growth in profits over the past two years. \\
\hline \multicolumn{2}{|c|}{ ROLE CLARITY } \\
\hline ROLE5 & $\begin{array}{l}\text { In our family business clearly demarcated areas of authority and responsibility exist between my spouse and } \\
\text { I. }\end{array}$ \\
\hline ROLE 2 & My spouse and I have agreed on each other's positions of authority and responsibility in our family business. \\
\hline ROLE 4 & In our family business a clearly defined division of labour exists between my spouse and I. \\
\hline ROLE 1 & My spouse and I have agreed on each other's roles and positions in our family business. \\
\hline \multicolumn{2}{|c|}{ NEEDS ALIGNMENT } \\
\hline NEED4 & I can realise my personal goals through my involvement in our family business. \\
\hline NEED5 & I can realise my ambitions through my involvement in our family business. \\
\hline NEED6 & $\begin{array}{l}\text { My involvement in this business together with my spouse has contributed to my own professional growth and } \\
\text { development. }\end{array}$ \\
\hline
\end{tabular}


Appendix 1: Items measuring constructs - continued

\section{PHYSICAL RESOURCES}

\begin{tabular}{|c|c|}
\hline PHYS3 & Our family business has adequate access to the necessary equipment required to function effectively. \\
\hline PHYS1 & Our family business has adequate access to the resources required to function effectively. \\
\hline PHYS2 & Our family business has sufficient access to information required to function effectively. \\
\hline \multicolumn{2}{|c|}{ GOVERNANCE } \\
\hline GOV1 & My spouse and I have a vision for our family business. \\
\hline GOV2 & My spouse and I have agreed on the future direction for our family business. \\
\hline GOV3 & My souse and I have policies (ground rules), which guide (govern) our actions and decisions. \\
\hline GOV4 & My spouse and I have agreed on the vision for our family business. \\
\hline GOV5 & My spouse and I undertake formal strategic planning for our family business. \\
\hline \multicolumn{2}{|c|}{ LEADERSHIP } \\
\hline LEAD3 & $\begin{array}{l}\text { The spouse that takes the lead in our family business encourages others involved in the business to } \\
\text { voice their opinions. }\end{array}$ \\
\hline LEAD6 & The spouse that takes the lead considers the opinions of others when making decisions. \\
\hline LEAD1 & $\begin{array}{l}\text { The spouse that takes the lead in our family business is always considerate of others working in the } \\
\text { business. }\end{array}$ \\
\hline LEAD2 & $\begin{array}{l}\text { The spouse that takes the lead in our family business inspires loyalty among those working in the } \\
\text { business. }\end{array}$ \\
\hline
\end{tabular}


